\title{
Legitimacy of Intellectual Property in the Law of Iran
}

\author{
Mehdi Pirhaji ${ }^{1}$, Solmaz Khodapanahandeh ${ }^{2} \&$ Maryam Rafiei $^{2}$ \\ ${ }^{1}$ Faculty of Human Science and Law, Khorasgan (Isfahan) Branch, Islamic Azad University, Isfahan, Iran \\ ${ }^{2}$ Faculty of Law, Universiti Kebangsaan Malaysia, Bangi, Selangor \\ Correspondence: Mehdi Pirhaji, Faculty of Human Science and Law, Khorasgan (Isfahan) Branch, Islamic Azad \\ University, Isfahan, Iran. Tel: 98-91-3119-8926. E-mail: mahdi_pirhaji@yahoo.com
}

Received: May 21, 2013 Accepted: October 23, 2013 Online Published: December 31, 2013

doi:10.5539/ass.v10n1p283 URL: http://dx.doi.org/10.5539/ass.v10n1p283

\begin{abstract}
Intellectual property right is a new law concept which determines the manner of protection and the use of human intellectual creation. Iran joined to the international public union known as Paris Convention in 1959 for protecting the agricultural, industrial and commercial property. Though Iran has not yet joined to the Berne Convention, by approving different laws regarding to the property of authors, composers, artists, software designers and inventors, Iran protects them. In the history of Iranian law, protection of industrial property takes precedence over literary and artistic property. There is dispute among Islamic jurists and scholar about the legitimacy of moral right and that is the main reason of Iran for not joining to the Berne Convention. The main goal of this research is to obtain more knowledge about Iranian law regarding to Legitimacy of moral property in Iran Law. The main method for gathering information here is library type and the main tools are using books, magazines and internet data. The method of research is descriptive.
\end{abstract}

Keywords: Iran, law, intellectual, property, copyright, legitimacy

\section{Introduction}

The language caused intimacy and affection among members of different societies and by the invention of hand writing, this communication was developed. After that, literature and art were created and each became the communicative language of modern communities. Painting, theatre, sculpturing, architecture, translation and cinema and so on, are all the branches of this robust root but all those who are the creators of such precious artistic and literary works are under the protection of law now. Berne Convention in 1886 (in Swiss) is considered as the start point of evolutions in such protections. Iran has joined the International Public Union known as Paris Convention in 1958 to protect the industrial, commercial and agricultural property, although it has not yet joined Berne Convention (Salehi, 2012).Iran has also passed and enforced the law of protecting the rights of authors, composers, artists, in 1969 (Saket, 2005).

Intellectual property for the first time was officially recognized in England in 1709 (Hamiyati Vaghef, 2011). Since more than one century ago, the international endeavors for the development of laws supervising the right of intellectual property has been done under the considerations of World. The most important convention in this regard was Paris Convention in 1883, which Iran joined it in 1959 (Colston, 2005) but Berne Convention (in Swiss) in 1884 is the most important convention regarding the intellectual property and Iran has not yet joined it.

Todays, intellectual property law has manifested as one of the main branches of law science. Different changes in man's life, specialization of legal professions, complication of economic relations, development of communications and technology are among the factors of growth and promotion of this matter. At the present time, one of the most important agreements are Trips agreements which are concerning copyright and the other related rights, trademarks, geographical indications, industrial design, and patents. This agreement takes into consideration the commercial aspects of the intellectual property right. Copyright, lexically, means duplication or the right of the author (Raeisi, 2009). In expression, it refers to the rights of the creators of literary, artistic and scientific works and can include a wide range of works such as: written, audio-visual, ideogramic works, crafts, carpet and drugget design, and computer software. Taking a brief look at the legitimacy of intellectual property in Iran law, this study makes an effort to provide a better understanding of this right in Iran. This is an analytical study with the purpose of providing a systematic and precise explanation of the laws and properties of research subject, in this study it was attempted to give a systematic and objective analytically of the Legitimacy of moral 
Intellectual Property Rights in Iranian law. The method of gathering information in this study was library type, and the main tools were journals, books, and internet databases.

\section{Intellectual Property in the Law of Iran}

The first time such a right was given to an author refers back to 1709 (Amoozgar, 2003). The law of copyright in England was known as the 'Queen's Law' (Anne); it also began in France in 1977 with the command of Louis the Sixteen; and in America, this law first began by making local laws in 1783 and then in 1789 was manifested as one of the principles of Constitution. Undoubtedly, National Law's protection of the moral property rights will not be effective until it is protected by the international conventions (Vaezi nezhad, 2003).

The intellectual property right is a new legal concept which is to determine the quality of protecting and using man's intellectual creations (Esmaeli, 2006). Intellectual property contains two main parts of industrial property and artistic - literary property. Industrial property protects the patents for invention, industrial designs, trademarks or service marks, trade names, trading right, etc. artistic - literary property protects the artistic and literary and other related works. The substance of intellectual property right is to protect the creator of the work and to prepare a safe ground to motivate artists and craftsmen to create better works, aiming the other sectors of the society benefit from them by getting familiar with the originality of such works (Mahmoudi, 2012). Intellectual property right in Iran has often been translated as moral ownership (Dehkhoda, 2012). By this kind of property, it means the right resulted from man's thought and intellectuality. Katouzian defined the moral rights as "the right empowered its owner to exploit and monopolize the man's activity, thought and creativity" (Katouzian, 1997). The subject matters under the protection of this right include man's intellectual works and innovative creations.

By developing societies, gradually the man's other innovations and creations added to the subject matters protected by this right. In English speaking countries and the United States the word 'copyright', in German the word 'Urheberrecht', means 'the right of writers', and in French the word 'droitdauteur', is used in the sense of literary - artistic property (Layeghi, 2001).

In the Universal Declaration of Human Rights, and the International Covenant on the Economic, Social, Cultural, Civil and Political Rights, enjoying the material and moral interests, and the necessity of taking appropriate measures to provide protection, development and promotion of the literary and artistic works have also been emphasized by government. Holding several international and regional conventions in this regard is the evidence of the universal concerns regarding this subject matter (Imami, 1992). Therefore, the intellectual property in a broad sense consists of all the rights resulted from the intellectual creations and innovations in scientific, industrial, literary and artistic fields (Bozorgi, 2003).

Iran legislator has not defined the moral right, but according to different Articles of the law which have been passed in 1969andby using the comparative law, it can be defined as follows: "moral rights are legal and immaterial benefits related to the creator of the work, by virtue of which he can always be entitled to a set of certain rights" (Entezari, 2006). The study of the content of copyright begins due to this right. This right legally refers to the relationship which link the work to its creator. It is due to such a right that the creator may be entitled to special privileges which will remain in force, even after his death. This right can transfer the combination of the work to the inheritors or the successors of the deceased author with preserving his name. Intellectual property rights are usually divided into two areas:

1) Industrial property right

2) Copyright and its peripheral rights (Hazrati, 1999).

Copyright lexically means duplicating or the right of the author, but in legal terms, it refers to the rights of the creators of scientific, literary and artistic works which encompasses wide range of written, audio-visual and ideogram works and also crafts, carpet, rug cartons and software (Eslami, 2009).

Using the experiences of other countries which have Police of software crimes, and by justifying the 110 Police regarding the different kinds of software crimes, Iran Police Force rapidly and seriously set out to pursuit such crimes. For example, following the claim of Sina software firm regarding the illegal copying of its productions in Mashhad, the Police Force took action to identifying and arresting the respective perpetrators (Rokni Dezfooli, 2006).

According to the Law of Islamic Republic of Iran, one who creates a work through his own knowledge, art or innovation is referred to as 'creator' and what is created by his activity, creativity and innovation, is considered as 'work'. The work which is created with the cooperation of two or more persons in way that their work cannot be discriminated is called 'joint work'. According to Iran law the rights of the creator who has been involved in 
generating or creating a work in any form, will be protected by law regardless the way he created or invented the work.

\section{Legitimacy of Moral Property in Iran Law}

Everyone knows that the software condition is now different form that in two decades ago. It can be claimed that at the present, software has penetrated all areas of man's life; and from industry and trade to the medicine and other human sciences, all have been affected by this newly emerging phenomenon (Vakil 2009). It can firmly be said that in the next decade software, in its general sense, will become one of the main inseparable apparatus of human societies, and the world planners of social systems will certainly pay special attention to this phenomenon as a key feature in their major planning.

The experience of the recent two decades shows obviously that the wave of software development and innovation, rooted in the USA, has reached developed Asian countries, UAE and Taiwan, after nearly two years from its invention, and its effect in Iran manifested two years after its entrance to Asia. Using CD, as one of the main media for storing data, and other related hardware; and public trends toward using internet, are evidences in supporting this idea (Azari, 1982).

It can be concluded from the above mentioned that legal system is an integral part of the software industry and if software is to be considered as one of the necessities of the Muslims' social system, it should be bounded to its appliances. As we proved that software will be a key factor in human's future life, we should inevitably accept the 'computer right system' (Shabiri, 2001). Moreover, although in the last century, trade relations were limited to the geographical boarders, today, thanks to the new media like internet network, the interpersonal communication between people all around the world will be possible, geographical boarders can be eliminated in economic relations, and the trade and transactions will take a universal meaning. Undoubtedly, technology and information should play the most important role in formulating the new system of world trade.

It should be kept in mind that although the general meaning of 'the necessity of stability or lack of disturbance(disorder) in the society' is a fixed proposition accepted by all the sapient in the world and not belonged to any specific era, the instances of this rational proposition are in every era different from that in other eras, and in every society different from that in other societies (Sherafat, 2005).With respect to the above mentioned, there is no doubts that it is necessary to pay special attention to software as a key issue to keep the order of the society and to prevent disorder in or collapse of the society. On the other hand, because the software has its own specific characteristics, its existence and survival demands the fulfillment of order and laws ruling over it. In the other words, the prerequisite for software to be developed as a national industry and to last for a long time is that a computer right system is formulated and come in force alongside it.

The debate of copyright has not been found in any jurisprudence chapters and in the works of the old Islamic jurists, and also there is no Hadith in this regard. Hence, this right is among the new issues which called 'updated issues' by contemporary Islamic jurists (Gorji, 1992).

In the last generation of contemporary Shia jurists, there is a few who believe in intellectual and moral property rights. Among these jurists, it can be referred to the founder of the Islamic Republic of Iran, Imam Khomeini, who considered the intellectual property rights as illegal.

Arguing for the updated issues, Imam Khomeini said in his book 'Tahrir al-Vasilah': what is known as copyright among people is not a legitimate right and eliminating the domination of people upon their property, without stipulating any condition or making any contract, is not allowed and just writing the sentence "copyright reserved' neither creates any right to the creator of the work nor obliges other to follow it; therefore, other people can copy and publish it and no one can prevent them from doing it. Also what is known as 'patent for invention' and prevents other form imitating the inventor or and from copying his/her invention, is not legally binding and no one can be forbidden from imitating him/her or trading the invention. Also no one can prevent others from dominating his/her own properties. Also what people know as 'monopolizing the trade of a specific commodity' by a company or a number of traders is not legally binding and preventing others from lawful trading and industry and monopolizing it for some specific individuals is not allowed. Also, price-fixing and preventing the individual from selling his property in advance at any price he/she wants, is not allowed. Of course, the ruler or anyone who holds any authority upon the Muslims has the right of pricing the commodities, industries, monopolizing the trading or doing anything else for the interests of Muslims (Khomeini Vaghef, 1987).

Also it can be pointed to Ayatollah Khoeiand Ayatollah Safi Golpayegani, as to other instances of the contemporary Shia jurists who do not consider moral property right as valid (Safi, 1984).

Issuing Fatwa on moral property right and answering the then Minister of Culture, Ayatollah Khamenei, the 
religious leader of Iran, said: "believing in the intellectual property right for the domestic authors and composer, is quite a rational matter but concluding contract with other countries regarding copyright is not advised; rather it is harmful and contrary to the interests of the country" (Yazdani, 2003).In contrast, some other Islamic scholars have accepted the moral property right. In response to a request for legal formal opinion (Estefta), Ayatollah Makarem Shirazi, one of the major Grand Ayatollahs of Shia, has said: "we believe that the copy right and patent for invention are legal rights and should be respected in the view of Islam." The rationale for such a claim is that we always take subjects from the custom, and judgments from Islamic Law. For example, when we say gambling is prohibited, the word prohibition has taken from Quran and Hadith (tradition)but what is the subject of gambling? It depends on the custom. The same is true in the case of intellectual property right. Islam says that oppressing other people and violating their rights is prohibited. This law has taken from Islam; while its subject, oppression and violation of rights, should be taken from custom; and today, almost all of the scholars in the world consider intellectual property as a right and believe that violating it is a kind of oppression (Rouhani, 1993).

Although the Law of protecting the rights of authors, writers and artists has been ratified in National Council of Iran in 1969, the executive procedure was not regulated and it did not enforced. Concordant with the victory of Islamic revolution in Iran, one of the laws which was engaged in ambiguity was the aforementioned law. Because some courts of Iran by referring to the decree of Imam Khomeini (the founder of Islamic Republic of Iran) refrained from the issuance of any order in accordance with the ratified law of 1969. For instance, in judgment No. 215 dated 25/ July/ 1984, the General Legal Court of Tehran issued following verdict:

By considering Imam Khomeini' decree in the book Tahrir Al Vasile, although this verdict is contrary to the law of 1969 (law of protecting the rights of authors, writers and artists), the Imam's decree has preference over that law. Therefore, the claim of plaintiff was rejected from this court. After that, the plaintiff objected on the mentioned verdict and this judgment was cancelled in Appeal Court of Tehran during the judgment No. 562 dated 9/ January/ 1984. The reason of mentioned court was that, the law is the basis of issuance of orders in courts and it has preference over decree. Furthermore, the principle 167 of Iranian Constitutional law indicates that the basis of each order should be in registered law (Hamyati -e Vaghef, 2011).

Then, ambiguity and obscurity about the legitimacy of 1969 law in Iran continued many years and lasted until 1992. In that time, the Minister of Culture and Islamic Guidance provided an inquiry letter from Minister of Justice (Ayatollah Yazdi) in the case of copy right and publishing. Given answer to this question was a milestone in the discussion of legitimacy of intellectual property in Iran. In fact, this letter missive and correspondence contained a legal justification in order to protect literary and artistic properties in Iran. Furthermore, after Islamic revolution, this letter provided a solution for better issuance of judicial verdicts in different courts of Iran and finally led to the ratification of supplementary rules in this case. The most notable examples were the approval of the protective law from the creators of computer software dated 24/ December/ 2000 and then, the accession of Islamic Republic of Iran to the convention of World Organization of Intellectual Property. This accession was ratified by Islamic parliament in 26/ September/ 2001, and legal system of Iran coordinated with the global developments in the field of protecting intellectual property.

According to mentioned cases, it seems that in current circumstances, there is no ambiguity about the validity of literary and artistic properties in law of Iran and also by removing the legal and religious doubts; this branch of law science is evolving gradually. However, the accession of Islamic Republic of Iran to the convention of World Organization of Intellectual Property does not mean the acceptation of treaties which are managed in this organization and the attendance of Iran in mentioned convention does not create legal obligation (Amiri, 2009). All of stated issues are within the scope of domestic relations and there is no obligation concerning foreign relations.

\section{Conclusion}

The first time such a right was given to an author refers back to 1709. The law of copyright in England was known as the 'Queen's Law' (Anne); it also began in France in 1977 with the command of Louis the Sixteen; and in America, this law first began by making local laws in 1783 and then in 1789 was manifested as one of the principles of Constitution. Undoubtedly, National Law's protection of the moral property rights will not be effective until it is protected by the international conventions. The intellectual property right is a new legal concept which is to determine the quality of protecting and using man's intellectual creations.

Today, the main role in industry and sustainable development is played by science production. Therefore, the states have an important and bilateral role in this regard. Moral property rights are dependent on the creator's personality and characterized by decision making on the publication of the work, the right of having 
guardianship on the work, the right of respecting the work and the right of restoration of the work. Some law, like the law of intellectual property right in France has explicitly mentioned all the four characteristics, while the others have only referred to the second and third one. In the present law of Iran, right of guardianship on the work and the right of respecting the work are explicitly stipulated.

Intellectual property right, in general sense, means the rights resulted from intellectual creativity and innovation in scientific, industrial, literary and artistic areas (Hachette, 2001). Iran joined the International Public Union known as Paris Convention in 1959 for the protection of industrial, commercial and agricultural property; however, it has not yet joined the Berne Convention, due to some Islamic jurisprudence considerations. But, passing diverse national laws including the law of the protection of authors, composers and artists rights in 1969, and the law of the protection of software creators' rights in 2000, and the law of patent for inventions, industrial designs, and trademarks in 2008, Iran shows its protection of the moral property. Notwithstanding the differences regarding the legitimacy of moral property in Islamic Law, Iran legislator has accepted it, although has not yet joined the Berne Convention because of the lack of criticism and decision making about all its aspects.

The Founder of the Islamic Republic of Iran, Imam Khomeini, considered intellectual property right as essentially illegal, because in his view, knowledge is for all the human beings and pricing it will deprive the other form their of gaining knowledge. In the contrary, Ayatollah Makarem Shirazi, one of the major Shia Grand Ayatollahs and of the major Islamic scholar in Iran, claims that copyright and the patent for invention and the like, are all legal and legitimate rights and Islam respect them; therefore, accepting such rights is not contrary to the Islam. What is obvious is that today computer software, books, new inventions, etc. have transformed all the aspects of man's life, and all human sciences from trade to medicine and from industry to human sciences and law are affected by such new phenomena as internet. Therefore, undoubtedly, Muslims' social system should treat thoughtfully in facing such situations, and pave the way for the development of his society alongside the international society.

Consistent with the Islamic revolution in Iran, the enforcement of 1969 law (right of literary and artistic property) got into trouble and some court of Iran by referring to the decree of Imam Khomeini refrained from the issuance of any order in accordance with that ratified law. However, following the judicial developments and by considering the Article 187 of constitutional law in Iran, new verdicts and comments of Islamic jurisprudents provided a legal justification in order to protect literary and artistic properties in Iran and finally led to the ratification of supplementary rules in this case, namely, the accession of Islamic Republic of Iran to the convention of World Organization of Intellectual Property which was ratified by Islamic parliament in 26/ September/ 2001 (Latifi, 2010). Nevertheless, the mentioned changes and developments were mostly in domestic law and next steps in this case for joining to global standards is needed yet. It can be concluded that what prevents Iran from complete joining and company to the global conventions is ambiguities about the jurisprudential perceptions of legitimacy. However, it seems that these obscurities are removing quickly and Iran is getting ready to company with treaties and international conventions.

\section{References}

Amiri, H. A. (2009). Enforcement of industrial property right in WTO regulation \& Iranian law, Tehran. Mizan legal foundation, 96-105.

Amoozgar, M. (2003). Copyright and other related rights. Journal of Legal Researches, 3, 38.

Azari, K. (1982). Creator's copyright. Journal of Law and Political Sciences Faculty of University of Tehran, 22, 8.

Bozorgi, V. (2001). Intellectual property right in WTO. Journal of Commercial Examinations, 1, 33.

Bozorgi, V. (2003). World Trade Organization, Intellectual Property Rightsand the Developing Countries. Journal of Political Economic Information, 173\&174, 192.

Colston, C. (2005). Principles of Intellectual Property Law (2nd ed.). London, Cavendish publishing limited.

Dehkhoda, A. (2012). Dictionary (Vol. 2.). Tehran, University Publication.

Entezari, A. R. (2006). Moral property. Basirat Journal, 30\&31, 38.

Eslami, S. (2009). Intellectual and industrial property (1st ed.). Tehran, Majd Publication.

Esmaeli, M. (2006). Protecting from literary, artistic properties and their transformation route in law of Iran. The Judiciary's Law Journal, 50\&51, 46.

Gorji, A. (1992). Moral Property and its Award. Informatics, (3\&4), 16. 
Hachette, C. (2000-2001). What is intellectual property and how does it differ from other forms of property ownership? Intellectual Property Law. University of Aberdeen.

Hamyati-eVaghef, A. A. (2011). Intellectual property. Tehran: Javdaneh publication.

Hazrati Shahin dej, S. (1999). Comparative Study of Copyright. Research Journal of Imam Sadegh University, $10,158$.

Imami, N. (1992). Intellectual Property Rights. Rahnemoon Journal, 2\&3, 137.

Katouzian, N. (1997). Preliminary Period of Civil Rights (6th ed.). Tehran,Mizan Publication.

Khomeini Vaghef, A. (1987). Registration of Moral Property (1st ed.). Tehran, Javdane Publication.

Khomeini, R. (2010). Tahrir al-wasilah (Vol. 4, 12th ed.). Qom, Dar al-maktab al-Ilmiyah Publication.

Latifi, M. (2010). Moral Property Rights. Marefat Journal, 152, 19.

Layeghi, G. R. (2001). The alphabet of copyright (1st ed.). Tehran, Khaneye Ketab Publication.

Mahmoudi, A. (2012). The Nature of Intellectual Property Right and its Place in Property Law. Journal of Legal Civil knowledge, 1, 2, 94-107.

Raeisi, L. (2009). The manners of intellectual property dispute settlement. Tehran: Jungle publication.

Rokni Dezfooli, M. R. (2006). Comparative study of moral property in Iran law and WTO. Marefat Journal, 106, 58.

Rouhani, M. S. (1993). Updated issues (1st ed.). Qom, Dar al-kitab Publication.

Safi, L. A. (1984). Altazir Anvae Va Molhaghaat. Institute of Islamic Publication.

Saket, M. H. (2005). The rights of intellectual property, history and theory. The Judiciary Law Journal, 50\&51, 88.

Salehi, H. R. (2012). The works under the protection of intellectual and industrial property of Iran. Roshd technology Journal, (32), 45.

Shabiri, S. H. (2001). Legal Responsibilities Resulted From the Faulty Software. Unpublished master thesis, University of Mokhayyer.

Sherafat, A. H., \& Mirhosseini, S. H. (2005). The importance of intellectual property rights on sustainable development. Ketabemah Review, (99\&100), 5-13.

Vaezi nezhad, A. (2003). Worldwide organization of intellectual property (WIP), Journal of Islamic Books, 8, 41.

Vakil, A. S. (2009). Intellectual property protection in W.T.O and Iranian legal system. Tehran: Majd publication, 77-79.

Yazdani, A. (2003). Copyright in the thoughts of contemporary Shia jurists. Journal of Islamic books, 9, 37.

\section{Copyrights}

Copyright for this article is retained by the author(s), with first publication rights granted to the journal.

This is an open-access article distributed under the terms and conditions of the Creative Commons Attribution license (http://creativecommons.org/licenses/by/3.0/). 